\title{
SHORT COMMUNICATION \\ Differentiation between the Genera Mycobacterium, Rhodococcus and Nocardia by Susceptibility to 5-Fluorouracil
}

\author{
By MICHIO TSUKAMURA \\ The National Chubu Hospital, Obu, Aichi, Japan 474
}

(Received 17 February 1981)

\begin{abstract}
A test for susceptibility to 5-fluorouracil was useful for differentiating between species of rapidly growing mycobacteria, and for differentiating the genus $R$ hodococcus from the genus Nocardia. The majority of rhodococci tested were susceptible to 5-fluorouracil $\left(20 \mu \mathrm{g} \mathrm{ml}^{-1}\right)$, whereas the majority of nocardiae tested were resistent to it. Strains of Nocardia asteroides sensu stricto could be divided into two subgroups by their reaction to 5 -fluorouracil.
\end{abstract}

\section{INTRODUCTION}

Tsukamura (1971) proposed a new genus, 'Gordona', for slightly acid-fast organisms occurring in sputa of patients with pulmonary disease, and in soil. Subsequently, Tsukamura (1973) included 'Mycobacterium' rhodochrous (Gordon \& Mihm, 1957; Gordon, 1966) as a member of 'Gordona', together with a new species, 'Gordona' aurantiaca (Tsukamura \& Mizuno, 1971). Tsukamura (1974a) proposed the revival of Rhodococcus as the generic name for this taxon, and the following six species were described: $R$. rhodochrous, $R$. bronchialis, $R$. rubropertinctus, $R$. terrae, ' $R$. roseus' and ' $R$. aurantiacus'. Goodfellow \& Alderson (1977) carried out an extensive study on these organisms and formally defined the genus Rhodococcus. Rhodococcus is closely related to Nocardia and, to a lesser extent, to Mycobacterium (Tsukamura, 1971); a number of characteristics which are useful for differentiating these three genera have been studied (Tsukamura, 1971, 1974 $a, b$; Goodfellow \& Alderson, 1977; Tsukamura et al., 1979). However, it is still important to establish some simple definitive tests for differentiating Rhodococcus from Nocardia. In the present study, susceptibility to 5-fluorouracil was shown to achieve this, and also to differentiate between species of rapidly growing mycobacteria and subgroups of Nocardia asteroides.

\section{METHODS}

The strains used were ones maintained in this laboratory. They were cultivated on Ogawa egg medium at $37^{\circ} \mathrm{C}$ for $3 \mathrm{~d}$ (M. flavescens and $M$. thermoresistibile for $5 \mathrm{~d}$ ) for use as inocula. The composition of the Ogawa egg medium was: basal solution $\left[1 \%(\mathrm{w} / \mathrm{v}) \mathrm{KH}_{2} \mathrm{PO}_{4}\right.$ and $1 \%(\mathrm{w} / \mathrm{v})$ sodium glutamate], $100 \mathrm{ml}$; whole eggs, $200 \mathrm{ml}$; glycerol, $6 \mathrm{ml} ; 2 \%(\mathrm{w} / \mathrm{v})$ aqueous solution of malachite green, $6 \mathrm{ml}$ (resulting $\mathrm{pH} \mathrm{6.8).} \mathrm{5-Fluorouracil}$ (Kyowa Fermentation Co., Tokyo) was dissolved in propylene glycol to give a concentration of $10 \mathrm{mg} \mathrm{ml}^{-1}$. This solution was diluted with distilled water to give concentrations of $4.0,2 \cdot 0,1.0$ and $0.5 \mathrm{mg} \mathrm{ml}^{-1}$, and $1 \mathrm{vol}$. of each dilution was added to 100 vol. Ogawa egg medium before sterilization, giving final concentrations of 5-fluorouracil of 40,20,10 and $5 \mu \mathrm{g} \mathrm{ml}^{-1}$. The medium was poured in $7 \mathrm{ml}$ portions into tubes $(165 \times 16.5 \mathrm{~mm})$, which were sloped after sterilization at $90^{\circ} \mathrm{C}$ for $60 \mathrm{~min}$.

One loopful (about $0.1 \mathrm{mg}$ wet wt) of the test strain was inoculated on to the Ogawa egg medium containing the various concentrations of 5 -fluorouracil. After inoculation, each tube was loosely stoppered with a doubleedged gum cap having a $3 \mathrm{~mm}$ cut in its centre, and incubated at $37^{\circ} \mathrm{C}$ for $3 \mathrm{~d}(M$. flavescens and $M$. thermoresistibile for $5 \mathrm{~d}$ ). Positive growth was regarded as growth similar to that on control medium, which contained no 5-fluorouracil. 


\section{RESULTS AND DISCUSSION}

The results obtained are shown in Table 1. The nocardiae were resistant to 5-fluorouracil at $40 \mu \mathrm{g} \mathrm{ml}^{-1}$ (except for some strains of $N$. asteroides and $N$. brasiliensis); most of the rhodococci, however, were susceptible to $5 \mu \mathrm{g} \mathrm{ml} \mathrm{m}^{-1}$, although some strains of $R$. rubropertinctus, $R$. corallinus and $R$. terrae were somewhat less susceptible. Most of the rhodococci could be differentiated from most of the nocardiae by their susceptibility to

Table 1. Tolerance to 5-fluorouracil of rapidly growing mycobacteria. rhodococci and nocardiae

Species

Mycobacterium

Rapidly growing, non-photochromogenic

$M$. fortuitum

M. chelonei subsp. chelonei

$M$. chelonei subsp. abscessus

M. smegmatis

M. chitae

'M. agri'

Rapidly growing, photochromogenic

$M$. vaccae

$M$. parafortuitum

Rapidly growing, scotochromogenic

M. flavescens

M. thermoresistibile

M. phlei

M. aurum

$M$. neoaurum

'M. obuense'

'M. aichiense'

'M. chubuense'

'M. rhodesiae'

Kanazawa strains (see text)

Rhodococcus

$R$. rhodochrous

$R$. bronchialis

R. rubropertinctus

R. terrae

$R$. ruber ('R. lentifragmentus') $\dagger$

$R$. corallinus

R. equi

$R$. coprophilus

Nocardia

$N$. asteroides subgroup A

$N$. asteroides subgroup B

$N$. farcinica

N. brasiliensis $\ddagger$

$N$. otitidis-caviarum

$N$. autotrophica

'Gordona' aurantiaca
No. of

tested

10
10
10
5
5
5

5

5

5

3

\section{5}

5

5

5

5

5

5

\section{5}

5

2

\section{8}

10

10

10

5

2
2

2

10
11
10
5
8
2

10

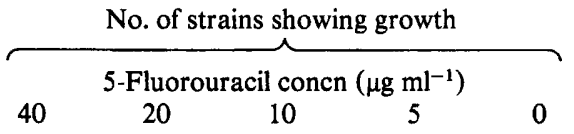

40

20

10

* Slight growth.

† See Tsukamura et al. (1975).

$\ddagger$ Strains resistant to $40 \mu \mathrm{g} \mathrm{m} \mathrm{m}^{-1}$ were 23083 (M199), 23104 (R405) and 23106 (R887); strains sensitive to $5 \mu \mathrm{g} \mathrm{ml}^{-1}$ were 23086 (M204) and 23105 (R432). 
Table 2. Strains of Nocardia asteroides placed into subgroups $A$ and $B$ on the basis of susceptibility to 5-fluorouracil

\begin{tabular}{|c|c|c|}
\hline & Strain no. & Source* \\
\hline Subgroup A & $\begin{array}{l}23007 \dagger \\
23012 \dagger \\
23039 \dagger \\
23046 \dagger \\
23049 \dagger \\
23064 \\
23094 \\
23099 \\
23206 \\
23202\end{array}$ & 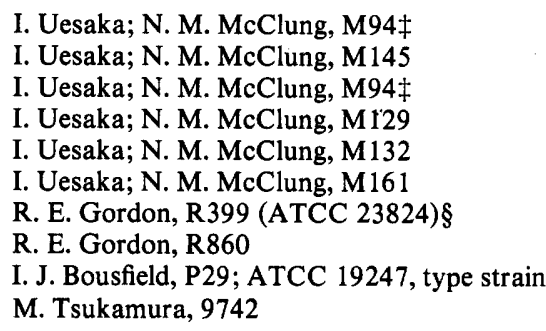 \\
\hline Subgroup B & $\begin{array}{l}23006 \dagger \\
23019 \\
23032 \dagger \\
23038 \dagger \\
23044^{\dagger} \\
23088^{\dagger} \\
23095 \dagger \\
23096 \\
23203 \\
23204 \\
23205\end{array}$ & $\begin{array}{l}\text { I. Uesaka; N. M. McClung, M93‡ } \\
\text { I. Uesaka; N. M. McClung, M78 } \\
\text { I. Uesaka; N. M. McClung, M10 } \\
\text { I. Uesaka; N. M. McClung, M93 } \\
\text { I. Uesaka; N. M. McClung, M124 } \\
\text { I. Uesaka; N. M. McClung, M206 } \\
\text { R. E. Gordon, R443(1) } \\
\text { R. E. Gordon, R443(2) } \\
\text { M. Tsukamura, } 9867 \\
\text { M. Tsukamura, } 9868 \\
\text { M. Tsukamura, } 9869\end{array}$ \\
\hline
\end{tabular}

* I. Uesaka, Kyoto University, Kyoto, Japan; N. M. McClung, University of South Florida, Tampa, Florida, U.S.A.; R. E. Gordon, Rutgers University, New Brunswick, New Jersey, U.S.A.; I. J. Bousfield, Torry Research Station, Aberdeen, Scotland.

† Strains placed into subgroups A and B by Tsukamura (1977) and Tsukamura et al. (1979).

$\ddagger$ Strains received from Dr I. Uesaka.

$\S$ Strain deposited in the American Type Culture Collection by Tsukamura (1969) as reference strain.

5 -fluorouracil at $20 \mu \mathrm{g} \mathrm{ml}^{-1}$. The strains of Nocardia asteroides could be divided into those tolerant to 5-fluorouracil at $20 \mu \mathrm{g} \mathrm{ml}^{-1}$ (subgroup A) and those susceptible at this concentration (subgroup B). The rapidly growing mycobacteria could also be divided into two distinct groups: those tolerant to $20-40 \mu \mathrm{g} \mathrm{ml}^{-1}$ and those susceptible to $5 \mu \mathrm{g} \mathrm{ml}^{-1}$.

Susceptibility to 5-fluorouracil is therefore considered to be a useful tool for differentiating Rhodococcus from Nocardia, the former being more susceptible than the latter. 'Gordona' aurantiaca (Tsukamura \& Mizuno, 1971) was considered not to belong to Rhodococcus or Nocardia (Goodfellow et al., 1978; Tsukamura et al., 1979). This taxon could be distinguished from rhodococci but not from nocardiae by this test.

Previously, strains of $N$. asteroides were considered as homogeneous (Gordon \& Mihm, 1957, 1962). Tsukamura (1969) divided strains received as $N$. asteroides into two distinct taxa, $N$. asteroides sensu stricto and $N$. farcinica, the latter containing strain ATCC 3318 (the type strain of $N$. farcinica). In a subsequent study (Tsukamura, 1977), the taxon $N$. asteroides sensu stricto itself appeared to be divided into two subgroups, A and B. In a numerical analysis of nocardiae, rhodococci and mycobacteria, subgroup A appeared distinct from rhodococci and closely related to the other nocardiae, while subgroup B was intermediate between Rhodococcus and Nocardia (Tsukamura et al., 1979). The subgroups A and $\mathrm{B}$ of $N$. asteroides defined in these previous studies corresponded to those distinguished here (Table 2). Subgroup A, previously shown to be closely related to other nocardiae, was tolerant to 5-fluorouracil as were other nocardiae. In contrast, subgroup B, previously shown to be related to rhodococci, was more susceptible to 5-fluorouracil as were the rhodococci tested. 
Previously, Tsukamura (1979) tested the susceptibility to 5-fluorouracil of slowly growing mycobacteria and observed that almost all slowly growing mycobacteria, except $M$. triviale, were relatively susceptible to this agent. In the present work, rapidly growing mycobacteria were studied. One group was tolerant to $20-40 \mu \mathrm{g} \mathrm{ml}^{-1}$ and contained $M$. fortuitum, $M$. chelonei subsp. chelonei, $M$. chelonei subsp. abscessus, $M$. smegmatis and $M$. parafortuitum. The other group was susceptible to $5 \mu \mathrm{g} \mathrm{m}^{-1}$ and contained $M$. flavescens, $M$. thermoresistibile, $M$. phlei, $M$. chitae, 'M. agri', $M$. aurum, $M$. neoaurum, 'M. obuense', $M$. vaccae, ' $M$. aichiense', ' $M$. chubuense' and ' $M$. rhodesiae'. The 'Kanazawa strains' had previously been identified as $M$. parafortuitum by Tsukamura (unpublished). However, these were suggested to be distinct from $M$. parafortuitum by Saito et al. (1977). The results here support this conclusion.

\section{REFERENCES}

Goodfellow, M. \& Alderson, G. (1977). The actinomycete-genus Rhodococcus: a home for the 'rhodochrous' complex. Journal of General Microbiology 100, 99-122.

Goodfellow, M., Orlean, P. A. B., Collins, M. D., Alshamaony, L. \& Minnikin, D. E. (1978). Chemical and numerical taxonomy of strains received as Gordona aurantiaca. Journal of General Microbiology 109, 57-68.

Gordon, R. E. (1966). Some strains in search of a genus - Corynebacterium, Mycobacterium, Nocardia or what? Journal of General Microbiology 43, 329-343.

Gordon, R. E. \& MiHM, J. M. (1957). A comparative study of some strains received as nocardiae. Journal of Bacteriology 73, 15-27.

Gordon, R. E. \& Mirm, J. M. (1962). The type species of the genus Nocardia. Journal of General Microbiology 27, 1-10.

Saito, H., Gordon, R. E., Juhlin, I., KÄPpleR, W., Kwapinski, J. B. G., McDurmont, C., Pattyn, S. R., Runyon, E. H., Stanford, J. L., TARnOK, I., TASAKa, H., Tsukamura, M. \& Weiszfeiler, J. (1977). Cooperative numerical analysis of rapidly growing mycobacteria. The second report. International Journal of Systematic Bacteriology 27, 75-85.

Tsukamura, M. (1969). Numerical taxonomy of the genus Nocardia. Journal of General Microbiology 56, 265-287.

TsukamurA, M. (1971). Proposal of a new genus, Gordona, for slightly acid-fast organisms occurring in sputa of patients with pulmonary disease and in soil. Journal of General Microbiology 68, 15-26.
TsukamURA, M. (1973). A taxonomic study of strains received as 'Mycobacterium' rhodochrous. Description of Gordona rhodochroa (Zopf; Overbeck; Gordon et Mihm) Tsukamura comb.nov. Japanese Journal of Microbiology 17, 189-197.

TsukAmURA, M. (1974a). A further numerical taxonomic study of the rhodochrous group. Japanese Journal of Microbiology 18, 37-44.

TsukAmurA, M. (1974b). Differentiation of the ' $M y c o-$ bacterium' rhodochrous-group from nocardiae by $\beta$-galactosidase activity. Journal of General Microbiology 80, 553-555.

TsukAmuRA, M. (1977). Extended numerical taxonomy study of Nocardia. International Journal of Systematic Bacteriology 27, 311-323.

TSUKAMURA, M. (1979). In vitro susceptibility of mycobacteria, especially Mycobacterium intracellulare, to 5-fluorouracil and pattern of development of resistance of Mycobacterium tuberculosis to the drug. Microbiology and Immunology 23, 427429.

Tsukamura, M. \& Mizuno, S. (1971). A new species Gordona aurantiaca occurring in sputa of patients with pulmonary disease. Kekkaku 46, 93-98.

Tsukamura, M., Mizuno, S. \& Murata, H. (1975). Numerical taxonomy study of the taxonomic position of Nocardia rubra reclassified as Gordona lentifragmenta Tsukamura nom.nov. International Journal of Systematic Bacteriology 25, 377-382.

Tsukamura, M., Mizuno, S., Tsukamura, S. \& Tsukamura, J. (1979). Comprehensive numerical classification of 369 strains of Mycobacterium, Rhodococcus, and Nocardia. International Journal of Systematic Bacteriology 29, 110-129. 